\title{
Effect of Cage or Deep Litter Housing on Production Performance of White Leghorn Chickens
}

\author{
V.V. Sonkamble ${ }^{1}$, A.K. Srivastava ${ }^{1 *}$, M.M. Pawar ${ }^{2}$, H.D. Chauhan ${ }^{1}$, K.J. Ankuya ${ }^{1}$ and A.K. Jain ${ }^{1}$ \\ ${ }^{1}$ Department of Livestock Production and Management, College of Veterinary Science and Animal Husbandry, \\ Sardarkrushinagar Dantiwada Agricultural University, Sardarkrushinagar, Gujarat, INDIA \\ ${ }^{2}$ Department of Animal Nutrition, College of Veterinary Science and Animal Husbandry, Sardarkrushinagar Dantiwada \\ Agricultural University, Sardarkrushinagar, Gujarat, INDIA \\ "Corresponding author: AK Srivastava; E-mail: aksrivastavavet@gmail.com
}

Received: 07 Oct., 2019

Revised: 19 March, 2020

Accepted: 23 March, 2020

\begin{abstract}
The effect of cage or deep litter housing on production performance of White Leghorn was investigated in this experiment. A total 144 pullets of White Leghorn were randomly assigned to two treatments as; Cage housing and Deep litter housing. Results revealed that body weight at sexual maturity was significantly $(\mathrm{P}<0.05)$ lower in birds reared in cage than the deep litter housing. Moreover, lower feed intake was observed in birds kept in cages than that of deep litter housing. Feed conversion ratio in terms of feed intake/dozen eggs or feed intake/kg egg mass was better in birds reared in cages than the deep litter housing. The average hen day and hen house egg production were not affected due to different housing systems. Egg quality traits like albumen index, yolk index and Haugh unit score were significantly $(\mathrm{P}<0.05)$ higher for eggs produced by birds reared in cage housing than the deep litter housing. The profit of about $20 \%$ was observed in cage housing over deep litter housing. It was concluded that the lower feed consumption and body weight at sexual maturity, better feed conversion, egg quality and economic returns were achieved in cages compared to deep litter housing. However, cage or deep litter housing had no effect on egg production.
\end{abstract}

Keywords: Cages, Deep litter, Egg production, Egg quality, Economics

The chicken egg is one of the finest foods, offering men an almost complete balance of essential nutrients with proteins, vitamins, minerals and fatty acids of great biological value (Adam, 2017). Moreover, it plays very vital role in meeting the nutritional requirements of the growing population in the developing countries. Feed and housing are two main factors of successful poultry farming business. Housing is important for raising layer poultry commercially and in small scale. The housing system is an external factor that influences both the performance of hens and the egg quality characteristics (Englmaierova et al., 2014). Before the use of conventional cage systems, hens had been kept mainly in small to medium-sized flocks in barn or free-range systems. It is apparent that every system has advantages and disadvantages in relation to animal/bird health, welfare and performance. Although the cage system of housing laying hens is the most economical and limits sanitary problems, the productivity and health of birds are better than in other systems (Sosnowka-Czajka et al., 2010; Jones et al., 2014). However, there are serious welfare disadvantages in the cage systems (Mench et al., 2011). The lack of free movement, comfort, shelter, suitable flooring and freedom to display most normal patterns of behavior has aroused many discussions about poultry welfare (Appleby, 2003; Mench et al., 2011). Housing laying hens in cages is a controversial animal welfare issue for the egg industry with impacts on public acceptance of current industry practices and the potential to lead to imposed changes which may be associated with increased capital costs (Elson, 1992;

How to cite this article: Sonkamble, V.V., Srivastava, A.K., Pawar, M.M. Chauhan, H.D., Ankuya, K.J. and Jain, A.K. (2020). Effect of cage or deep litter housing on production performance of White Leghorn chickens. J. Anim. Res., 10(2): 263-268. 
Petek, 2015). Several alternative systems as deep litter, preacher, aviary, free range and enriched cage systems has been proposed and increasingly practiced in the past two decades. These alternative housing systems accommodate most of the welfare concerns that are found in battery cage housing systems. Very few studies have been conducted under Indian conditions to verify the suitability of cage or deep litter housing systems for laying hens with regards to production performance and health. Therefore, the present study was conducted to evaluate the growth and egg production performance of White Leghorn chickens reared under different housing systems.

\section{MATERIALS AND METHODS}

\section{Location of study and climatic conditions}

The present study was conducted at sub-department of Avian Production and Management of Department of Livestock Production and Management, College of Veterinary Science and Animal Husbandry, Sardarkrushinagar Dantiwada Agricultural University, Sardarkrushinagar which is located in semi arid region of Banaskantha District of North Gujarat having latitude of $24.35^{\circ}$ North and longitude of $72.59^{\circ}$ East. The in-house mean temperature during experimental period was ranged from 18.23 to $33.9{ }^{\circ} \mathrm{C}$, while the relative humidity was ranged from 38 to $79 \%$ and the mean rainfall reported during the experimental period was $305.1 \mathrm{~mm}$.

\section{Experimental design}

A total 144 pullets ( 8 weeks of age) of White Leghorn were randomly assigned in to two treatments viz., Cage housing system and Deep litter housing system. Each treatment had 72 birds with three replicates of 24 birds. In cage housing system floor space of 550 square centimeters per bird was provided. The stocking density in deep litter system was 5 birds $/ \mathrm{m}^{2}$. The birds were fed standard diet as per BIS (2007) specification to meet their nutrient requirements. The ingredients and chemical composition of diet fed to birds during different phases are presented in table 1 . The chemical compositions of diets were determined as per the procedures of AOAC (1995). The feed and water were provided as per standard rearing protocol. The birds were weighed individually at the beginning of the experiment
( $8^{\text {th }}$ week of age) and thereafter at the interval of two weeks during growing phase. Age at sexual maturity in days and body weight at sexual maturity in grams were also recorded.

\section{Egg production and quality}

To determine layer performance parameters like age at first egg, average weekly feed intake, feed conversion ratio (feed intake/dozen eggs and feed intake/kg egg mass), hen daily production and egg weight were recorded. The egg quality was monitored as egg shape index, shell thickness, yolk index, albumen index and Haugh unit. Egg collection was carried out twice a day. Feed were weighed at the beginning of the week and left over feed at the end of each week were recorded for the calculation of average feed intake. Egg weight was measured with sensitive scale calibrated in grams. The width and the length of the eggs were measured with the aid of Vernier caliper calibrated in centimeters. Egg width (maximum) was divided by the egg length (maximum) to get the egg shape index. Shell thickness was measured with micrometer screw gauge. Yolk height and width were measured with a ruler calibrated in centimeter with the aid of optical pins and mathematical compass. Yolk index was calculated as the ratio of the yolk height to the yolk width. Similarly, albumin height and width were measured and albumin index was calculated as the ratio of the albumin height to the albumin width. To calculate the Haugh unit, the following formula was used (Cotta, 1997): $\mathrm{HU}=100 \mathrm{Log}$ $(\mathrm{h}-1.7 \mathrm{w}+7.6)$ where, $\mathrm{HU}=$ Haugh unit, $\mathrm{h}=$ albumen height $(\mathrm{mm})$ and $\mathrm{w}=$ egg weight $(\mathrm{g})$.

\section{Return over feed cost (ROFC)}

The effect of different housing systems on economics was determined in terms of return over feed cost and profit gained. The prevailing prices of feed used and sale price of eggs in local market were considered. All other cost components of production i.e. cost of chick, medicines, vaccine and other overhead were taken as constant for both the treatment groups.

\section{STATISTICAL ANALYSIS}

The data obtained from experiment were statistically analyzed using one-way analysis of variance using 
SPSS statistical software package (Version 16.0, SPSS Inc, Chicago, USA). Significant differences among the treatments were determined with Duncan's multiple range tests. Statistical significance was set at $\mathrm{P}<0.05$.

\section{RESULTS AND DISCUSSION}

\section{Growth performance, feed intake and feed conversion ratio}

The effect of different housing systems on growth performance of White Leghorn pullets is represented in Table 2. The initial average body weights were $656.50 \pm 6.80$ and $645.11 \pm 6.55 \mathrm{~g} /$ bird in cage and deep litter housing groups, respectively at 8 weeks of age. The birds in cage housing had lower body weights at $16^{\text {th }}$, $18^{\text {th }}$ and $20^{\text {th }}$ week of ages than the deep litter birds. The body weights (g/bird) at $20^{\text {th }}$ week were $1402.94 \pm 9.10$ and $1472.66 \pm 7.81$ in cage and deep litter housing groups, respectively. The rearing of birds in either cage or deep litter housing system did not have significant effects on age at first egg and age at sexual maturity (Table 3 ). Body weight at sexual maturity was significantly $(\mathrm{P}<0.05)$ lower in birds reared in cage $(1361.61 \pm 8.05 \mathrm{~g})$ than the deep litter $(1387.30 \pm 8.57 \mathrm{~g})$ housing. In agreement with our results Singh et al. (2009) also reported that the body weight of hens in the floor system was found to be higher compared to the ones in the caged systems.

Table 1: Ingredients and chemical composition of chick, grower and layer diet

\begin{tabular}{llll}
\hline Ingredients (\%) & $\begin{array}{l}\text { Chick (0-8 } \\
\text { weeks) }\end{array}$ & $\begin{array}{l}\text { Grower (9-20 } \\
\text { weeks) }\end{array}$ & $\begin{array}{l}\text { Layer (21-40 } \\
\text { weeks) }\end{array}$ \\
\hline Maize grain & 40.0 & 40.0 & 50.0 \\
Soya bean meal & 33.0 & 18.0 & 26.0 \\
De-oiled Rice Barn & 20.0 & 20.0 & 12.0 \\
Rice Polish & 6.60 & 21.0 & 6.00 \\
Limestone & - & 0.65 & - \\
Salt & 0.30 & 0.30 & 0.30 \\
Lysine & 0.03 & - & 0.02 \\
Methionine & - & - & 0.02 \\
Toxivin & 0.05 & 0.05 & 0.05 \\
Choline & 0.02 & - & - \\
Ventrimix & - & - & 0.01 \\
Shell girt & - & - & 5.6
\end{tabular}

\begin{tabular}{llll}
\multicolumn{4}{l}{ Chemical Composition (\%) } \\
Protein & 21.31 & 16.62 & 18.09 \\
Fat & 6.31 & 3.57 & 4.68 \\
Fibre & 4.58 & 5.27 & 6.28 \\
Lysine* & 1.04 & 0.72 & 0.84 \\
Methionine* & 0.30 & 0.32 & 0.33 \\
Metabolizable & 2857.08 & 2875.50 & 2806.60 \\
energy* (Kcal/kg) & & & \\
\hline
\end{tabular}

"contains Vitamin A - 82,500 IU, Vitamin $\mathrm{B}_{2}$ - $50 \mathrm{mg}$, Vitamin $\mathrm{D}_{3}$ $12,000 \mathrm{IU}$, Vitamin K - $10 \mathrm{mg}$ per gram; *calculated values as fed basis.

Table 2: Effect of different housing systems on body weight of White Leghorn pullets $(n=144)$

\begin{tabular}{llll}
\hline Age in weeks & $\begin{array}{l}\text { Cage } \\
\text { housing }\end{array}$ & $\begin{array}{l}\text { Deep litter } \\
\text { housing }\end{array}$ & Significance \\
\hline $\mathrm{W}_{8}$ & $656.50 \pm 6.80$ & $645.11 \pm 6.55$ & $\mathrm{NS}$ \\
$\mathrm{W}_{10}$ & $717.75 \pm 6.57$ & $712.16 \pm 7.15$ & $\mathrm{NS}$ \\
$\mathrm{W}_{12}$ & $839.08 \pm 7.61$ & $831.08 \pm 7.51$ & $\mathrm{NS}$ \\
$\mathrm{W}_{14}$ & $968.66 \pm 7.91$ & $968.16 \pm 8.15$ & $\mathrm{NS}$ \\
$\mathrm{W}_{16}$ & $1131.83^{\mathrm{a}} \pm 8.62$ & $1173.58^{\mathrm{b}} \pm 8.12$ & $*$ \\
$\mathrm{~W}_{18}$ & $1248.61^{\mathrm{a}} \pm 8.93$ & $1328.80^{\mathrm{b}} \pm 8.69$ & $*$ \\
$\mathrm{~W}_{20}$ & $1402.94^{\mathrm{a}} \pm 9.10$ & $1472.66^{\mathrm{b}} \pm 7.81$ & $*$ \\
\hline
\end{tabular}

Means with different superscripts within the treatment groups differs significantly $\left({ }^{*} \mathrm{P}<0.05\right.$; NS: Not Significant).

Table 3: Effect of different housing systems on feed intake, feed conversion ratio and sexual maturity of White Leghorn $(n=144)$

\begin{tabular}{llll}
\hline Parameters & $\begin{array}{l}\text { Cage } \\
\text { housing }\end{array}$ & $\begin{array}{l}\text { Deep litter } \\
\text { housing }\end{array}$ & Significance \\
\hline Age at first egg (days) & $118.33 \pm 5.32$ & $116.33 \pm 8.32$ & $\mathrm{NS}$ \\
$\begin{array}{l}\text { Age at sexual maturity } \\
\text { (days) }\end{array}$ & $139.5 \pm 8.54$ & $133.66 \pm 9.17$ & $\mathrm{NS}$ \\
$\begin{array}{l}\mathrm{BW} \text { at sexual maturity } \\
(\mathrm{g})\end{array}$ & $1361.61^{\mathrm{a}} \pm$ & $1387.30^{\mathrm{b}} \pm 8.57$ & $*$ \\
$\begin{array}{l}\text { Feed intake }(\mathrm{kg})\left[\mathrm{W}_{20}-\right. \\
\left.\mathrm{W}_{40}\right]\end{array}$ & $22.53^{\mathrm{a}} \pm 0.17$ & $23.81^{\mathrm{b}} \pm 0.11$ & $*$ \\
$\begin{array}{l}\text { FCR [Feed intake/ } \\
\text { dozen eggs] }\end{array}$ & $2.13^{\mathrm{a}} \pm 0.26$ & $2.34^{\mathrm{b}} \pm 0.32$ & $*$ \\
$\begin{array}{l}\text { FCR [Feed intake/kg } \\
\text { egg mass }]\end{array}$ & $3.53^{\mathrm{a}} \pm 0.43$ & $3.98^{\mathrm{b}} \pm 0.55$ & $*$ \\
\hline
\end{tabular}

Means with different superscripts within the treatment groups differs significantly $(* \mathrm{P}<0.05$; NS: Not Significant). 
Sonkamble et al.

Table 4: Effect of different housing systems on egg production performance of White Leghorn layers (n=144)

\begin{tabular}{|c|c|c|c|c|c|c|}
\hline Age in weeks & Cage housing & Deep litter housing & Significance & Cage housing & $\begin{array}{l}\text { Deep litter } \\
\text { housing }\end{array}$ & Significance \\
\hline & \multicolumn{3}{|c|}{ Hen Day Egg Production (\%) } & \multicolumn{3}{|c|}{ Hen House Egg Production (\%) } \\
\hline $20-22$ & 70.73 & 70.44 & NS & 70.73 & 70.44 & NS \\
\hline $22-24$ & 78.08 & 76.39 & NS & 78.08 & 76.39 & NS \\
\hline $24-26$ & 85.42 & 81.75 & NS & 85.42 & 81.75 & NS \\
\hline $26-28$ & 88.69 & 88.39 & NS & 88.69 & 88.39 & NS \\
\hline $28-30$ & 89.03 & 86.54 & NS & 87.80 & 82.94 & NS \\
\hline $30-32$ & 86.06 & 80.75 & NS & 79.96 & 77.38 & NS \\
\hline $32-34$ & 79.75 & 76.33 & NS & 74.11 & 70.93 & NS \\
\hline $34-36$ & 75.81 & 70.49 & NS & 69.35 & 65.48 & NS \\
\hline $36-38$ & 71.36 & 67.04 & NS & 64.29 & 61.41 & NS \\
\hline $38-40$ & 68.47 & 65.11 & NS & 61.61 & 59.62 & NS \\
\hline Overall & $79.33 \pm 1.43$ & $76.32 \pm 1.47$ & NS & $76.00 \pm 1.76$ & $73.47 \pm 1.71$ & NS \\
\hline
\end{tabular}

NS: Not Significant.

Significantly $(\mathrm{P}<0.05)$ lower feed intake was observed in birds kept in cage than that of deep litter housing. The higher feed intake in birds reared on deep litter housing may be due to their higher locomotor activity and as a result of this activity, might have consumed more feed as compared to the birds in cages. Similarly, Tauson et al. (1999) reported that the hens which were housed on litter had by approximately $10 \%$ higher feed consumption per day than hens from cages. Feed conversion ratio in terms of feed intake/dozen eggs or feed intake/kg egg mass was better in birds reared in cages than the deep litter housing. In line with the present findings, Leyendecker et al. (2001a) observed that White layer and Brown layer hens in free range system had a poorer feed conversion in comparison with cage housing. Ahammed et al. (2014) observed that Lohmann Brown hens in a barn system had a higher feed intake and feed conversion ratio than conventional cage system.

\section{Egg production}

The average hen day and hen house egg production (\%) were not affected due to different housing systems (Table 4). The hen day and hen housed egg production (HHEP) were 79.33 and $76.00 \%$ in cage housing and 76.32 and $73.47 \%$ in deep litter housing, respectively. The types of housing system affected the performance of laying hens. Better results were achieved in cages (e.g. lower feed consumption and conversion and higher economic return) compared to deep litter housing system. These results are in agreement with findings reported by Leyendecker et al. (2001a), Tumova and Ebeid (2003) and Englmaierova et al. (2014). Many researchers have reported that egg production of hens reared in different housing systems were found to be similar (Neijat et al., 2011; Ahammed et al., 2014) whereas some have reported that egg production was higher in cage systems than in barn and free range systems (Voslarova et al., 2006; Huneau-Salaun et al., 2011; Dikmen et al., 2016).

\section{Egg quality}

Egg quality traits like albumen index, yolk index and Haugh unit (HU) score $(\%)$ were significantly $(\mathrm{P}<0.05)$ higher for eggs produced by birds reared in cage housing than the deep litter housing (Table 5). A higher HU indicates a better internal egg quality (Haugh, 1937). While some authors found higher HU score in caged hens (Patterson et al., 2001; Hidalgo et al., 2008), others found a higher score in organic or free-range systems (Castellini et al., 2006; Dukic-Stojcic et al., 2009), or no difference among production systems (Kucukyılmaz et al., 2012). In present study cage housing has lead to decreased shell thickness (mm) of eggs when compared to deep litter housing. Similar findings were reported by many authors (Tumova and Ebeid, 2005; Lichovnikova and Zeman, 
2008; Tumova et al., 2009) who assessed effect of barn versus cage on egg shell quality indicated a higher quality of eggs from cages. Accordingly, Tumova et al. (2011) reported that eggshell thickness was lower in eggs that were produced in cages. Differences $(\mathrm{P}<0.05)$ between egg weight, albumen height, Haugh unit, and static compression shell strength in eggs from a commercial facility with hens housed in conventional cages, enriched colony cages, and cage-free aviaries were reported by Jones et al. (2014). Egg weight (g) and shape index (\%) were comparable and not influenced by the different housing systems. In contrast to the present findings, heavier eggs laid were observed in cage housing by Leyendecker et al. (2001b) and Tumova et al. (2011), whereas Tumova and Ebeid (2005), Pistekova et al. (2006) and Hidalgo et al. (2008) recorded heavier eggs on conventional housing system.

Table 5: Effect of different housing systems on egg quality characteristics of White Leghorn layers $(n=144)$

\begin{tabular}{llll}
\hline Parameters & $\begin{array}{l}\text { Cage } \\
\text { housing }\end{array}$ & $\begin{array}{l}\text { Deep litter } \\
\text { housing }\end{array}$ & Significance \\
\hline Egg weight (g) & $50.06 \pm 0.94$ & $49.73 \pm 0.83$ & NS \\
Shape index (\%) & $75.07 \pm 0.23$ & $74.93 \pm 0.22$ & NS \\
Shell thickness (mm) & $0.35^{\mathrm{a}} \pm 0.02$ & $0.36^{\mathrm{b}} \pm 0.01$ & $*$ \\
Albumen index (\%) & $7.84^{\mathrm{b}} \pm 0.07$ & $7.32^{\mathrm{a}} \pm 0.09$ & $*$ \\
Yolk index (\%) & $37.67^{\mathrm{b}} \pm 0.20$ & $36.69^{\mathrm{a}} \pm 0.18$ & $*$ \\
Haugh unit score (\%) & $74.91^{\mathrm{b}} \pm 0.39$ & $73.17^{\mathrm{a}} \pm 0.43$ & $*$ \\
\hline
\end{tabular}

Means with different superscripts within the treatment groups differs significantly $\left({ }^{*} \mathrm{P}<0.05\right.$; NS: Not Significant).

\section{Return over feed cost}

The lower total cost of feeding ( $₹ 34877.3$ vs. 37714.6) and higher numbers of egg produced (8007 vs. 7967) were observed in cage housing than the deep litter housing. The return over feed cost [ROFC] (₹) was 9161.2 and 6103.9 in cage and deep litter housing groups, respectively. In the present study, ROFC per egg was higher (1.14 vs. 0.77) in cage housing over deep litter housing. This may be due to lower feed intake and higher numbers of eggs produced in cage reared hens as compared to deep litter housed hens.
Table 6: Effect of different housing systems on feed cost economics of White Leghorn layers

\begin{tabular}{lll}
\hline Parameters & $\begin{array}{l}\text { Cage } \\
\text { housing }\end{array}$ & $\begin{array}{l}\text { Deep litter } \\
\text { housing }\end{array}$ \\
\hline Total feed intake $(\mathrm{kg})$ & 1622.2 & 1714.3 \\
Cost of feeding (₹ 22/kg of feed) & 34877.3 & 37714.6 \\
Total numbers of eggs produced & 8007 & 7967 \\
Income through sale of eggs (₹ 5.5/egg) & 44038.5 & 43818.5 \\
Return over feed cost [ROFC](₹) & 9161.2 & 6103.9 \\
ROFC per egg (₹) & 1.14 & 0.77 \\
\hline
\end{tabular}

\section{CONCLUSION}

It was concluded that the lower feed consumption and body weight at sexual maturity, better feed conversion, egg quality and economic returns were achieved in cages compared to deep litter housing. However, cage or deep litter housing had no effect on egg production.

\section{ACKNOWLEDGEMENTS}

We are grateful to the Director of Research, Sardarkrushinagar Dantiwada Agricultural University, Sardarkrushinagar, Gujarat for providing the necessary facilities and funding to carry out this research work.

\section{REFERENCES}

Adam, I.Y.I. 2017. Effect of deep-litter floor and battery cages system on the productive performance of commercial layers in Elobied, Sudan. Ph.D. Thesis, University of Kordofan, Sudan.

Ahammed, M., Chae, B.J., Lohakare, J., Keohavong, B., Lee, M.H., Lee, S.J., Kim, D.M., Lee, J.Y. and Ohh, S.J. 2014. Comparison of aviary, barn and conventional cage raising of chickens on laying performance and egg quality. Asian-Aust. J. Anim. Sci., 27(8): 1196-1203.

AOAC. 1995. Official Methods of Analysis. $15^{\text {th }}$ ed. Association of Analytical Chemists. Washington, DC, USA.

Appleby, M.C. 2003. The European Union ban on conventional cages for laying hens: History and prospects. J. Appl. Anim. Welf. Sci., 6: 103-121.

BIS. Bureau of Indian Standards 2007. Poultry Feeds Specifications. (5 $5^{\text {th }}$ Revision), Manak Bhawan, 9, Bahadur Shah Jafar Marg, New Delhi, India.

Castellini, C., Perella, F., Mugnai, C. and Dal Bosco, A. 2006. Welfare, productivity and qualitative traits of egg in laying 
hens reared under different rearing systems. Poster at: XII European Poultry Conference, Verona, Italy.

Cotta, T. 1997. Reprodução da galinha e produção de ovos. Lavras: UFLA-Faepe, 81-92.

Dikmen, B.Y, Ipek, A., Sahan, U., Petek, M. and Sozcu, A. 2016. Egg production and welfare of laying hens kept in different housing systems (conventional, enriched cage, and free range). Poult. Sci., 95(7): 1564-1572.

Dukic-Stojcic, M., Peric, L., Bjedov, S. and Milosevic, N. 2009. The quality of table eggs produced in different housing system. Biotechnol. Anim. Husb., 25(5-6): 1103-1108.

Elson, H.A. 1992. Evaluation of economic aspects of housing systems for layers. In Proceedings XIX World's Poultry Congress, Amsterdam, Netherlands, 2: 503-508.

Englmaierova, M., Tumova, E., Charvatova, V. and Skrivan, M. 2014. Effects of laying hens housing system on laying performance, egg quality characteristics, and egg microbial contamination. Czech J. Anim. Sci., 59(8): 345-352.

Haugh, R.R. 1937. The Haugh unit for measuring egg quality. U.S. Egg Poult. Magazine, 43: 552-555.

Hidalgo, A., Rossi, M., Clerici, F. and Ratti, S. 2008. A market study on the quality characteristics of eggs from different housing systems. Food Chem., 106(3): 1031-1038.

Huneau-Salaun, A., Guinebretiere, M., Taktak, A., Huonnic, D. and Michel, V. 2011. Furnished cages for laying hens: study of the effects of group size and litter provision on laying location, zootechnical performance and egg quality. Animal, 5(6): 911-917.

Jones, D.R., Karcher, D.M. and Abdo, Z. 2014. Effect of a commercial housing system on egg quality during extended storage. Poult. Sci., 93(5): 1282-1288.

Kucukyilmaz, K., Bozkurt, M., Herken, E.N., Cinar, M., Catl, A.U., Bintas, E. and Coven, F. 2012. Effects of rearing systems on performance, egg characteristics and immune response in two layer hen genotype. Asian-Aust. J. Anim. Sci., 25(4): 559-568.

Leyendecker, M., Hamann, H., Hartung, J., Kamphues, J., Ring, C., Glunder, G., Ahlers, C., Sander, I., Neumann, U. and Distl, O. 2001a. Analysis of genotype-environment interactions between layer lines and housing systems for performance trails, egg quality and bone strength. $1^{\text {st }}$ Communication: Performance traits. Zuchtungskunde, 73: 290-307.

Leyendecker, M., Hamann, H., Hartung, J., Kamphues, J., Ring, C., Glunder, G., Ahlers, C., Sander, I., Neumann, U. and Distl, O. 2001b. Analysis of genotype-environment interactions between layer lines and housing systems for performance trails, egg quality and bone strength. $2^{\text {nd }}$ Communication: Egg quality traits. Zuchtungskunde, 73: 308-323.

Lichovnikova, M. and Zeman, L. 2008. Effect of housing system on the calcium requirement of laying hens and on eggshell quality. Czech J. Anim. Sci., 53: 162-168.
Mench, J.A., Sumner, D.A. and Rosen-Molina, J.T. 2011. Sustainability of egg production in the United States - The policy and market context. Poult. Sci., 90(1): 229-240.

Neijat, M., House, J.D., Guenter, W. and Kebreab, E. 2011. Production performance and nitrogen flow of Shaver White layers housed in enriched or conventional cage systems. Poult. Sci., 90(3): 543-554.

Patterson, P.H., Koelkebeck, K.W., Bell, D.D., Carey, J.B., Anderson, K.E. and Darre, M.J. 2001. Egg marketing in national supermarkets: Specialty eggs - part 2. Poult. Sci., 80(4): 390-395.

Petek, M., Cavusoglu, E., Topal, E., Unal, C., and Abdourhamane, I.M. 2015. Effects of slatted floor housing on animal welfare in broiler production. Proceedings of $3^{\text {rd }}$ International Poultry Meat Congress, 22-26 April 2015, Antalya, Turkey.

Pistekova, V., Hovorka, M., Vecerek, V., Strakova, E. and Suchy, P. 2006. The quality comparison of eggs laid by laying hens kept in battery cages and in a deep litter system. Czech $J$. Anim. Sci., 51(7): 318-325.

Singh, R., Cheng, K.M. and Silversides, F.G. 2009. Production performance and egg quality of four strains of laying hens kept in conventional cages and floor pens. Poult. Sci., 88(2): 256-264.

Sosnowka-Czajka, E., Herbut, E. and Skomorucha, I. 2010. Effect of different housing systems on productivity and welfare of laying hens. Ann. Anim. Sci., 10(4): 349-360.

Tauson, R., Wahlstrom, A. and Abrahamsson, P. 1999. Effect of two floor housing systems and cages on health, production, and fear response in layers. J. Appl. Poult. Res., 8(2): 152159 .

Tumova, E. and Ebeid, T. 2003. Effect of housing system on performance and egg quality characteristics in laying hens. Sci. Agric. Boh., 34: 73-80.

Tumova, E. and Ebeid, T. 2005. Effect of time of oviposition on egg quality characteristics in cages and in a litter housing system. Czech J. Anim. Sci., 50: 129-134.

Tumova, E., Skrivan, M., Englmaierova, M. and Zita, L. 2009. The effect of genotype, housing system and egg collection time on egg quality in egg type hens. Czech J. Anim. Sci., 54: 17-23.

Tumova, E., Englmaierova, M., Ledvinka, Z. and Charvatova, V. 2011. Interaction between housing system and genotype in relation to internal and external egg quality parameters. Czech J. Anim. Sci., 56: 490-498.

Voslarova, E., Hanzalek, Z., Vecerek, V., Strakova, E. and Suchy, P. 2006. Comparison between laying hen performance in the cage system and the deep litter system on a diet free from animal protein. Acta. Vet. Brno., 75(2): 219-225. 